\title{
Technology-neutral auc- tions for renewable energy: EU law vs. Member State reality
}

\section{An assessment of the EU Environmental and Energy State Aid Guidelines 2014-2020 and their application}

\author{
Lars Jerrentrup ${ }^{\mathrm{a}}$, Bastian Lotz ${ }^{\mathrm{b}}$, Silvana Tiedemann ${ }^{\mathrm{b}, \mathrm{c}}$, Lion Hirth ${ }^{\mathrm{d}, \mathrm{e}, \mathrm{f}}$ \\ a Aurora Energy Research GmbH \\ ${ }^{b}$ Navigant Energy Germany $\mathrm{GmbH}$ \\ ${ }^{c}$ Karlsruhe Institute of Technology (KIT), Germany \\ ${ }^{d}$ Neon Neue Energieökonomik GmbH (Neon), Germany \\ ${ }^{e}$ Mercator Research Institute on Global Commons and Climate Change (MCC), Germany \\ ${ }^{f}$ Hertie School of Governance
}

Corresponding author: Lion Hirth, hirth@neon-energie.de, Karl-Marx-Platz 12, 12043 Berlin

Abstract - European Union competition law, intended to thwart subsidies paid out by national governments, plays an important role in shaping EU Member States' support schemes for renewable energy. The Environmental and Energy State Aid Guidelines 2014-2020, which formalize the European Commission's take on subsidies in the electricity sector, prescribe technology-neutral auctions as the standard mechanism to determine support levels. In this study, we have assessed the formal decisions of the Commission with respect to technology-neutrality between July 2014 and May 2018. It turns out that 16 out of 18 schemes are not technology-neutral and figure high degrees of technology-differentiation. We have also studied the exemption clauses invoked to justify technology-discrimination, finding that the most ambiguous clause is used most frequently, and that the application and level of scrutiny varies strongly from case to case. The State Aid Guidelines are meant to increase transparency and legal certainty. We find that with respect to technology-neutral auctions for renewable energy, the Guidelines fail to deliver on their purpose.

Keywords: renewable energy auctions; State Aid Guidelines; EEAG 


\section{Introduction}

Electricity from renewable energy sources (RES-E) is on the rise. Global wind and solar power capacity for electricity generation has reached $900 \mathrm{GW}$, after annual additions exceeded $100 \mathrm{GW}$ three years in a row ${ }^{1}$, outstripping the combined additions of nuclear, natural gas and coal capacity ${ }^{2}$. As of 2017, wind and solar energy supply more than $10 \%$ of all electricity in as many as 14 out of 33 member states of the International Energy Agency. ${ }^{3}$

Auctions for RES-E have played an important role in driving the boom. In the last decade, the number of countries having implemented procurement auctions for RES-E increased more than tenfold, from 6 in 2005 to more than 67 by $2016 .{ }^{4}$ One reason for the rapid adoption of auctions as a policy instrument is the dramatic fall in prices in recent years. In 2016, countries such as Mexico, Chile, Peru, the US, and Morocco achieved prices for solar and wind below USD 40 per MWh. ${ }^{5}$ Records that were undercut shortly after, e.g. with a bid of USD 18 per MWh for onshore wind in Mexico and USD 18 per MWh for solar in Saudi Arabia. ${ }^{6}$ In Germany and the Netherlands, offshore wind developers even refrained from public support and will refinance their projects entirely on the electricity market (BNetzA, 2017, 2018; RVO,

${ }^{1}$ REN21, Renewables 2017 Global Status Report, 2017.

${ }^{2}$ Bloomberg New Energy Finance (BNEF), New Energy Outlook 2018, 2017.

${ }^{3}$ International Energy Agency (IEA), Monthly electricity statistics, 2017, retrieved from http://www.iea.org/statistics/monthlystatistics/monthlyelectricitystatistics/.

${ }^{4}$ International Renewable Energy Agency (IRENA), Renewable Energy Auctions: Analysing 2016, 2017.

${ }^{5} \mathrm{Id}$.

${ }^{6}$ Centro Nacional de Control de Energía (CENACE), Anuncian SENER y CENACE Resultados Preliminares de La Tercera Subasta de Largo Plazo, 2017, retrieved from https://www.gob.mx/cenace/prensa/anuncian-sener-ycenace-resultados-preliminares-de-la-tercera-subasta-de-largo-plazo-141668. 
2018). ${ }^{7}$ According to the IEA, the global mean average price for the most recent auctions was below USD 50 per MWh for both wind and solar energy. ${ }^{8}$

RES-E auctions have many design parameters that determine success or failure, including auction procedure (static vs. dynamic, pricing rule et cetera), conditions for participation (technical requirements, financial bid bonds et cetera), deadlines and penalties (timing, fines for non-compliance), and the institutional setup. ${ }^{9}$ A particularly prominent design element in both the academic and policy debate is technology-discrimination, i.e. the question if separate technology-specific auctions for different generation technologies or joint technology-neutral auctions should be conducted. There is disagreement in the literature on the net benefits of technology-discrimination. The main argument in favor of introducing technology-neutral auctions pertains to the minimization of generation costs, i.e. creating static efficiency. Rationales usually brought forward to justify technology-discrimination include enhancing dynamic efficiency, minimizing total system costs, and promoting secondary policy objectives such as local industrial development, among others. ${ }^{10}$

${ }^{7}$ Federal Network Agency (BNetzA), WindSeeG - 2. Ausschreibung für bestehende Projekte Nach $§ 26$ WindSeeG - Ergebnisse der 2. Ausschreibung vom 01.04.2018 - Bekanntgabe der Zuschläge, 2018, retrieved from https://www.bundesnetzagentur.de/DE/Service-Funktionen/Beschlusskammern/1_GZ/BK6-

GZ/2018/2018_0001bis0999/BK6-18-001/Ergebnisse_zweite_ausschreibung.pdf?_blob=publicationFile\&v=3 Federal Network Agency (BNetzA), WindSeeG - 1. Ausschreibung für bestehende Projekte Nach $§ 26$ WindSeeG - Ergebnisse der 1. Ausschreibung vom 01.04.2017 - Bekanntgabe der Zuschläge, 2017, retrieved from https://www.bundesnetzagentur.de/DE/Service-Funktionen/Beschlusskammern/1BK-Geschaeftszeichen-Datenbank/BK6-GZ/2017/2017_0001bis0999/BK6-17-

001/Ergebnisse_erste_Ausschreibung.pdf?__blob=publicationFile $\& v=3$;

Netherlands Enterprise Agency (RVO), Nuon Wins Permit for Dutch Offshore Wind Farm without Subsidy, 2018, retrieved from https://english.rvo.nl/news/nuon-wins-permit-dutch-offshore-wind-farm-without-subsidy.

${ }^{8}$ International Energy Agency (IEA), Renewables 2017, 2017.

${ }^{9}$ Wigand, F. et al., Auctions for renewable energy support: Lessons learnt from international experiences.

AURES Report D4.2, 2016; Gephart, M., Klessmann, C. \& Wigand, F., Renewable energy auctions - When are they (cost-)effective?, Energy \& Environment 2016 (28), pp. 145-165.; IRENA, supra note 4 at p. 3.

${ }^{10} \mathrm{del}$ Río, P., Designing auctions for renewable electricity support. Best practices from around the world.

Energy for Sustainable Development 2017 (41), pp. 1-13.; Gephart, Klessmann \& Wigand, supra note 9; Kreiss, J. et al., Different cost perspectives for renewable energy support: Assessment of technology-neutral and 
The European Commission sees technology-neutral auctions as the preferred way of determining the level of payments in RES-E support schemes (such as feed-in-tariffs, feed-inpremiums, or contracts for differences). This objective has been enforced through state aid control as part of EU competition policy. In particular, the Environmental and Energy State Aid Guidelines 2014-2020 (EEAG), which formalize the EU Commission's approach to state aid control in the energy sector, prescribe technology-neutral auctions as the standard mechanism to determine support levels. However, the EEAG also provide a number of exemptions from this rule. Only recently. the principle of technology neutrality together with its exemption clauses have also found their way into the new Renewable Energy Directive (RED II). Yet, it seems that most EU Member States, who are in charge of designing support schemes subject to EU state aid control, continue to implement technology-specific auctions. This paper addresses this apparent discrepancy. We do so by analyzing European Commission decisions on Member States' RES-E support schemes that have been formally notified for mandatory state aid clearance. Based on a document analysis of all formal decision letters to Member States between 1 July 2014 and 31 May 2018, we are addressing two research questions:

(1) Are EU Member States implementing technology-neutral auctions? (They don’t.)

(2) Which exemptions stated in the EEAG are invoked by the EU Commission to justify derogations from the technology-neutrality requirement? (Mostly a broad, unspecific exemption clause.)

We find that out of 18 notifications, only two schemes are technology-neutral as notified. However, these two schemes have not been implemented yet, but those Member States have only committed themselves to introduce technology-neutral RES-E auctions in the future. All other notified support schemes subject to the technology-neutrality requirement deviate from this principle. Moreover, in all but two of these cases, the Commission draws on an exemption that is broad, vague and indeed quite tautological (Need for diversification) rather than relying on more precise exemptions stated in the EEAG (e.g. System costs and Network constraints). In other words, we find that the Commission readily accepts Member States'

discriminatory auctions, forthcomming, 2017.; Wigand et al., supra note 9 at p.4; Winkler, J., Magosch, M., \& Ragwitz, M., Effectiveness and efficiency of auctions for supporting renewable electricity - What can we learn from recent experiences?, Renewable Energy 2018 (119), pp. 473-489. 
justifications of technology-discrimination in their RES-E support schemes without thorough substantiation, and thus refrains from a strict hierarchical enforcement of the technology-neutrality requirement.

These findings are of particular legal and policy importance for the revision of the Environmental and Energy State Aid Guidelines for the period after 2020 and for the implementation of the recently agreed upon RED II. The RED II sets rules of general nature. It adopts technology-neutrality as a guiding principle and Member States may apply technology-specific auctions only by invoking the same exemption clauses currently foreseen in the State Aid Guidelines and discussed in this paper. The revision of the State Aid Guidelines is expected to start soon, i.e. in mid-2019. Both reforms of EU law will highly benefit from the systematic review of the past notifications conducted in this paper.

This paper proceeds as follows. Chapter 2 gives an overview of the EEAG and introduces a conceptual framework of technology-discrimination. The paper continues by describing the filters applied to identify relevant cases, the data set of the notification decisions, and the methodology for their evaluation in chapter 3. Chapter 4 and 5 discuss the first and second research question respectively. Chapter 6 concludes.

\section{Background}

This section provides legal and historical background on the EEAG and introduces our definition of technology-neutrality in RES-E auctions.

\subsection{The EEAG}

The single market is among the founding principles of the European Union and its predecessors. Until today, competition policy remains an area where the European Commission has far-reaching competencies, much more than in other policy fields such as energy. Fending off subsidies ("state aid") granted by national governments to domestic industry is among the prime objectives to implement the common market. The Commission regularly publishes sectoral guidelines specifying the principles of its application of state aid law in order to increase 
transparency, predictability and legal certainty for Member States; these are called State Aid Guidelines. ${ }^{11}$

In recent years, Member States' RES-E support policies have increasingly fallen within the scope of application of EU state aid law. ${ }^{12}$ This process was largely driven by the European Commission's 2014 decision to classify the German Renewable Energy Sources Act (EEG) from 2012 as state aid - setting up a precedent for subjecting Member States'RES-E support schemes to state aid control. Since then, Member States have principally been required to notify their support schemes to the Commission ahead of implementation. Through its legally binding decisions, the Commission has been entitled to ask Member States to abolish or alter unlawful schemes. Note in this context that while the Commission's decision on the EEG 2012 has recently been nullified by the ECJ in its ruling from 28 March $2019^{13}$, this has no automatic implications for the general applicability of EU state aid law to Member States' RES-E schemes at large. ${ }^{14}$ This is due to the limited scope of the ECJ ruling, which only assesses the state aid character of the EEG 2012, while other RES-E support schemes would still have to be assessed on a case-by-case basis.

For scrutinizing RES-E support schemes, the European Commission applies the EEAG. Their introduction in 2014 means a significant increase in the regulatory density of state aid law in

${ }^{11}$ F. Pause, Die Beihilfeleitlinien der Kommission für den Energie- und Umweltbereich - eine kritische Würdigung, in: T. Müller \& H. Kahl (eds.), Erneuerbare Energien in Europa, 2015, pp. 219-251.

${ }^{12}$ M.-C. Fuchs \& F. Peters, Die Europäische Kommission und die Förderung erneuerbarer Energien in Deutschland - Eine Bewertung des EEG-Beihilfeverfahrens und der neuen Umwelt- und Energiebeihilfeleitlinien mit einem kritischen Blick auf die Leitlinien der Kommission, Recht der Energiewirtschaft 2014, pp. 409-416; W. Michl, Der lange Arm des Staates - zur beihilfenrechtlichen Einordnung der EEG-Umlage, Zeitschrift für Europäisches Umwelt- und Planungsrecht 2016 (14), pp. 259-262; P. Stöbener de Mora, Das Urteil des EuG zum Beihilfecharakter des EEG 2012, Europäische Zeitschrift für Wirtschaftsrecht 2016 (27), pp. 539-542.

${ }^{13}$ ECJ Judgement: Case C-405/16 P, Federal Republic of Germany v European Commission [2019].

${ }^{14}$ Stiftung Umweltenergierecht, Das EEG 2012 ist keine Beihilfe - was genau bedeutet das EuGH-Urteil? Fragen und Antworten, Hintergrundpapier, Würzburger Berichte zum Umweltenergierecht Nr. 41, 2019, p. 7. 
the energy sector. ${ }^{15}$ The European Commission mentions increasing RES-E market integration and reducing RES-E support levels as their primary objectives. ${ }^{16}$ The EEAG include a number of detailed regulations on the design of RES-E support, significantly narrowing down the degrees of freedom of Member States. ${ }^{17}$

In principle, point 126 third and fourth paragraph EEAG requires that support is granted through "competitive bidding processes on the basis of clear, transparent and non-discriminatory criteria $[\ldots]$ open to all generators producing electricity from renewable energy sources on a non-discriminatory basis" ${ }^{18}$. In other words, support schemes (1) have to be based on auctions and (2) these auctions have to be technology-neutral. There are few exemptions from (1), such as a transitional phase (point 126 first paragraph EEAG) and de minimis rules for small-scale assets (point 127 EEAG), among others.

For this paper, we are interested in the exemptions from technology-neutrality (2) specified in the EEAG. Member States can introduce technology-specific auctions only if technology-neutrality would lead to a suboptimal result. As such, point 126 fifth paragraph EEAG lists the following justifications to derogate from the technology-neutrality requirement:

- (a) Longer-term potential of a given new and innovative technology (hereafter: Longer-term potential);

- (b) Need to achieve diversification (hereafter: Need for diversification);

- (c) Network constraints and grid stability (hereafter: Network constrains);

- (d) System (integration) costs (hereafter: System costs);

\footnotetext{
${ }^{15}$ H. Kahl, Viele Wege führen nach Rom: Die Preisfindung bei der Förderung erneuerbarer Energien im Beihilferecht der EU und Subventionsrecht der WTO, Zeitschrift für Umweltrecht 2015, pp. 67-73.

${ }^{16}$ European Commission, Impact Assessment accompanying the document Communication from the Commission Guidelines on State environmental protection and energy for 2014-2020, SWD(2014) 139, Brussels, 2014, retrieved from http://ec.europa.eu/smart-regulation/impact/ia_carried_out/docs/ia_2014/swd_2014_0139_en.pdf.

${ }^{17}$ E. Szyszczak, Time for Renewables to Join the Market: the New Guidelines on State Aid for Environmental Protection and Energy, Journal of European Competition Law \& Practice 2014 (5), pp. 616-623.

${ }^{18}$ Communication: Commission Communication on Guidelines on State aid for environmental protection and energy 2014-2020, OJ 2014 C 200/26.
} 
- (e) Need to avoid distortions on the raw material markets from biomass support

This list of exemption clauses is non-exhaustive. ${ }^{19}$

\subsection{Definition of Technology-Neutrality}

Defining technology-neutrality is more difficult than it seems at first glance. The aim of this section is to develop a conceptual framework that allows to categorize the multitude of realworld auction designs with respect to technology-discrimination. In the following, we define our understanding of technology-neutral, multi-technology, and technology-specific auctions. Multi-technology auctions are further differentiated by the presence of discriminatory elements within the partially grouped auctions.

By technologies, we refer to solar PV, onshore wind power, offshore wind power, biomass, hydroelectricity, geothermal, et cetera. We ignore any discrimination within technologies, e.g. location- or site-specific auctions, as our analysis focuses on between-technology discrimination.

We define technology-neutral RES-E auctions as

- competitive bidding processes

- without any formal restrictions on the participation of available technologies,

- in which neither negative nor positive technology-specific discriminatory rules exist explicitly or implicitly.

The definition is narrow and does not allow for any discrimination between technologies in the auction, i.e. during the selection of technologies. This is in line with the understanding of

\footnotetext{
${ }^{19}$ H. Münchmeyer, M. Kahles \& F. Pause, Erfordert das europäische Beihilferecht die Einführung von Ausschreibungsverfahren im EEG?, Würzburger Berichte zum Umweltenergierecht 2014, pp. 1-13.
} 
the Commission outlined in the EEAG, the accompanying impact assessment ${ }^{20}$, and a corresponding guidance document ${ }^{21}$. Our definition focuses on the auction as such, i.e. on the allocation mechanisms. It cannot capture discriminations by the support schemes itself. The support scheme can for example be more favorable for technologies with high investment compared to operational cost or vice versa, favor technologies with a specific market value et cetera. Such analysis is out of scope of this paper.

Multi-technology auctions may restrict participation to certain technologies and apply additional technology-specific discriminatory elements. Restricting the participation of technologies can be done by setting qualification requirements, which include technical specifications, local content and project size. ${ }^{22}$ As a result, technologies are effectively grouped according to certain characteristics, such as generation profile (e.g. California) or maturity level (e.g. UK). Multi-technology auctions can also incorporate additional discriminatory elements via quality-based or cost-based discrimination as part of the winner selection process. ${ }^{23}$ The former usually takes the form of multi-criteria auctions, in which additional criteria other than bid prices influence the bidder's score, such as $\mathrm{CO}_{2}$ footprint, geographic location, or local content. ${ }^{24}$ Cost-based discrimination comes in three flavors: introducing technologyspecific minimum or maximum quotas; granting bonus payments for certain technologies; or imposing technology-specific price ceilings. ${ }^{25}$ Note that we would classify an auction as

\footnotetext{
${ }^{20}$ European Commission, Impact Assessment accompanying the document Communication from the Commission Guidelines on State environmental protection and energy for 2014-2020, SWD(2014) 139, p. 42.

${ }^{21}$ European Commission, European Commission guidance for the design of renewables support schemes.
} Accompanying the document Communication from the Commission: delivering the internal market in electricity and making the most of public intervention. SWD(2013) 439 final, p. 7.

${ }^{22}$ International Renewable Energy Agency (IRENA) \& Clean Energy Ministerial (CEM), Renewable Energy Auctions : A Guide to Design, 2015.; Soysal, E. R., Pre-qualifications and penalties, AURES Policy Memo 2 , 2016.; Steinhilber, S., \& Soysal, E. R., Secondary objectives in auctions. AURES Policy Memo 1, 2016.

${ }^{23}$ Kreiss et al., supra note 10 at p. 4.

${ }^{24}$ Cantillon, E., Auctions for the support of renewables: when and how?, 2015.; Steinhilber \& Soysal, supra note 22.

${ }^{25}$ del Río, supra note 10 at p. 4.; Kreiss et al., supra note 10 at p. 4.; Kreiss, J., The effect of competition levels on auction outcomes. AURES Policy Memo 4, 2016.; Steinhilber \& Soysal, supra note 22. 
multi-technology with discriminatory elements in case an auction open to all available technologies applies discriminatory elements, such as technology-specific price ceilings. Due to the presence of discriminatory elements the auction cannot be considered technology-neutral according to our definition. For reasons of transparency and to enhance the relevance of the results, we therefore distinguish multi-technology auctions in multi-technology auctions with discriminatory elements and multi-technology auctions without discriminatory elements.

In technology-specific auctions, participation is restricted to only one technology, i.e. there are separate auctions per technology. Nonetheless, additional discriminatory elements in multi-technology auctions can also lead to de facto technology-specific auctions. ${ }^{26}$ For example, defining exhaustive technology-specific demand bands through quotas in multitechnology auctions could be interpreted as a sequence of technology-specific auctions organized in parallel. ${ }^{27}$

Figure 1 visualises our understanding of technology-neutral, technology-specific, and multitechnology auctions with and without additional discriminatory elements.

\begin{tabular}{|c|c|c|c|c|}
\hline \multirow{2}{*}{ 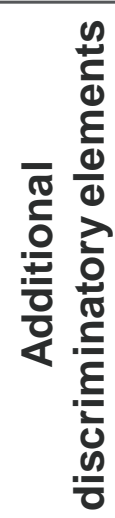 } & 离 & \multicolumn{2}{|c|}{$\begin{array}{l}\text { Multi-technology auctions with } \\
\text { discriminatory elements }\end{array}$} & \multirow{2}{*}{$\begin{array}{c}\text { Technology-specific } \\
\text { auctions }\end{array}$} \\
\hline & $\begin{array}{l}\stackrel{\oplus}{0} \\
\frac{1}{Z}\end{array}$ & $\begin{array}{l}\text { Technology-neutral } \\
\text { auctions }\end{array}$ & $\begin{array}{l}\text { Multi-technology } \\
\text { auctions without } \\
\text { discriminatory } \\
\text { elements }\end{array}$ & \\
\hline & & $t=T$ & $2 \leq \mathrm{t}<\mathrm{T}$ & $t=1$ \\
\hline & & \multicolumn{3}{|c|}{ Participating technologies } \\
\hline
\end{tabular}

Figure 1: Conceptual framework of technology-discrimination in RES-E auctions; $t$ = all participating technologies; $\mathrm{T}=$ all available technologies in a country

\footnotetext{
${ }^{26}$ Steinhilber \& Soysal, supra note 22 at p. 10.

${ }^{27}$ IRENA \& CEM, supra note 22 at p. 10.
} 


\section{Data and Methodology}

We conduct a qualitative document analysis of all European Commission state aid decisions on Member States' notified RES-E support policies, in which competitive bidding processes subject to the technology-neutrality requirement have been assessed on the legal basis of point 126 EEAG. State aid decisions were retrieved from the DG Competition's State Aid Cases Databank. We assessed all decisions between 1 July 2014 and 31 May 2018 of RES-E support policies based on comprehensive aid schemes and project-specific ad hoc individual aid, thus excluding individual aid granted on the basis of an aid scheme. Also, given that point 126 EEAG only applies to RES-E operating aid, we focus exclusively on RES-E support policies that at least partially rely on operating aid.

In a first step, a total of 54 notified RES-E support schemes were identified based on three search rounds conducted for aid schemes and ad hoc individual aid respectively, using different combinations of filters as documented in Table 1. In a second step, 28 schemes not featuring competitive bidding processes were removed from the sample. Lastly, another 8 cases are excluded, in which Member States have voluntarily introduced competitive bidding processes in the absence of a legally binding requirement. The remaining 18 RES-E support schemes provide the sample for our analysis and are summarized in Table 2. Note that four cases include notified amendments of existing schemes of the Netherlands (SA.39399, SA.46960) and UK (SA.47267, SA.49318), which have an impact on the degree of technology-discrimination and are thus included in the sample.

Table 1 Documentation of search filters used in the DG Competition's State Aid Cases Databank (last updated on 31 May 2018)

\begin{tabular}{|c|c|c|c|c|c|c|}
\hline & $\begin{array}{l}\text { Policy } \\
\text { Area }\end{array}$ & $\begin{array}{c}\text { Decision } \\
\text { Date: } \\
\text { From... }\end{array}$ & $\begin{array}{c}\text { Primary Objec- } \\
\text { tive (Main) }\end{array}$ & $\begin{array}{c}\text { EU Sec- } \\
\text { ondary } \\
\text { legal basis }\end{array}$ & $\begin{array}{l}\text { Case } \\
\text { type }\end{array}$ & $\begin{array}{c}\text { Number } \\
\text { of RES-E } \\
\text { support } \\
\text { policies } \\
(\mathrm{N}=54)\end{array}$ \\
\hline $\begin{array}{l}\text { First search } \\
\text { round }\end{array}$ & State Aid & - & - & EEAG & Scheme & 44 \\
\hline & State Aid & - & - & EEAG & $\begin{array}{l}\text { Ad Hoc } \\
\text { Case }\end{array}$ & 2 \\
\hline
\end{tabular}




\begin{tabular}{|c|c|c|c|c|c|c|}
\hline $\begin{array}{l}\text { Second } \\
\text { search } \\
\text { round }\end{array}$ & State Aid & 2014-07-01 & $\begin{array}{l}\text { Environmental } \\
\text { Protection }^{28}\end{array}$ & - & Scheme & 6 \\
\hline & State Aid & 2014-07-01 & $\begin{array}{l}\text { Environmental } \\
\text { Protection }\end{array}$ & - & $\begin{array}{l}\text { Ad Hoc } \\
\text { Case }\end{array}$ & $\mathbf{0}$ \\
\hline \multirow[t]{2}{*}{$\begin{array}{l}\text { Third } \\
\text { search } \\
\text { round }\end{array}$} & State Aid & 2014-07-01 & Renewable Energy & - & Scheme & 2 \\
\hline & State Aid & 2014-07-01 & Renewable Energy & - & $\begin{array}{l}\text { Ad Hoc } \\
\text { Case }\end{array}$ & $\mathbf{0}$ \\
\hline
\end{tabular}

Table 2 Overview of analyzed cases $(\mathrm{N}=18)$

\begin{tabular}{|c|c|c|c|c|}
\hline Case Number & Member State & Decision date & Title & $\begin{array}{l}\text { Notification } \\
\text { expiry }\end{array}$ \\
\hline SA.36196 & $\begin{array}{l}\text { United King- } \\
\text { dom }\end{array}$ & 2014-07-23 & Contract for Difference for renewables in UK & $2025-03-31$ \\
\hline SA.36023 & Estonia & 2014-10-28 & $\begin{array}{l}\text { Support scheme for electricity produced from re- } \\
\text { newable sources and efficient co-generation }\end{array}$ & $2020-12-30$ \\
\hline SA.39399 & Netherlands & 2015-04-07 & Modification of Dutch SDE+ RES scheme & 2019-12-31 \\
\hline SA.43995 & Malta & $2016-08-26$ & Competitive Bidding Process for RES in Malta & $2020-12-31$ \\
\hline SA.41998 & Slovenia & 2016-10-10 & $\begin{array}{l}\text { A) Support to electricity from renewable energy } \\
\text { sources and combined heat and power installations, } \\
\text { and B) Support for electro- intensive users in the } \\
\text { form of reductions in electricity support scheme con- } \\
\text { tributions }\end{array}$ & 2019-12-31 \\
\hline SA.45461 & Germany & $2016-12-20$ & EEG 2017 - Reform of the Renewable Energy Law & $2020-12-31$ \\
\hline SA.46259 & France & 2017-02-10 & $\begin{array}{l}\text { Appel d'offre sur } 60 \mathrm{MW} \text { pour installations hy- } \\
\text { droélectriques }\end{array}$ & N/A \\
\hline SA. 47267 & $\begin{array}{l}\text { United King- } \\
\text { dom }\end{array}$ & $2017-02-16$ & Amendment to UK CfD for RES & $2017-12-31$ \\
\hline SA.46552 & France & $2017-09-29$ & $\begin{array}{l}\text { Appels d'offres pour installations énergie solaire au } \\
\text { sol entre } 500 \mathrm{kWc} \text { et } 17 \mathrm{MWc}\end{array}$ & 2023-12-31 \\
\hline
\end{tabular}

\footnotetext{
${ }^{28}$ Note that the option Environmental Protection is listed twice in the official drop-down menu corresponding to the search filter "Primary Objective (Main)", with the two entries yielding different results. However, we accounted for this issue by conducting each search within the second search round twice, using both options labelled Environmental Protection respectively.
} 


\begin{tabular}{|c|c|c|c|c|}
\hline SA.47753 & France & 2017-09-29 & $\begin{array}{l}\text { Tender for PV installations on buildings with a rated } \\
\text { power between } 100 \mathrm{~kW} \text { and } 8 \mathrm{MW}\end{array}$ & $2023-12-31$ \\
\hline SA.48066 & France & 2017-09-29 & Appel d'offres triannuel pour l'éolien terrestre & 2023-12-31 \\
\hline SA.48238 & France & 2017-09-29 & $\begin{array}{l}\text { Soutien par appels d'offres au développement des in- } \\
\text { stallations de production d'électricité à partir de } \\
\text { l'énergie solaire photovoltaïque ou éolienne terrestre }\end{array}$ & 2023-12-31 \\
\hline SA.40348 & Spain & 2017-11-10 & $\begin{array}{l}\text { Support for electricity generation from renewable } \\
\text { energy sources, cogeneration and waste }\end{array}$ & 2024-06-10 \\
\hline SA.44076 & Hungary & 2017-11-30 & RES support scheme - METÁR & 2026-12-31 \\
\hline SA.49181 & France & 2017-12-11 & $\begin{array}{l}\text { Appel d'offres portant sur la réalisation et l'exploita- } \\
\text { tion d'installations hydroélectriques nouvelles } \\
\text { situées en France métropolitaine }\end{array}$ & 2022-05-01 \\
\hline SA.43697 & Poland & $2017-12-13$ & $\begin{array}{l}\text { Polish support scheme for RES and relief for en- } \\
\text { ergy-intensive users }\end{array}$ & $2025-12-31$ \\
\hline SA.48143 & Greece & 2018-01-04 & Auctions for RES and CHP support in Greece & $2025-12-31$ \\
\hline SA.49318 & $\begin{array}{l}\text { United King- } \\
\text { dom }\end{array}$ & 2018-02-01 & Support for wind energy on remote islands & 2025-03-31 \\
\hline
\end{tabular}

Finally, the two research questions are operationalized as follows. For the first research question, we investigate on the basis of their notified RES-E support schemes if Member States are implementing technology-neutral or discriminatory auctions. This is done by analyzing whether exemption clauses for derogations from technology-neutral auctions are assessed by the European Commission in its formal decision letters to Member States. Moreover, we classify analyzed cases according to our conceptual framework to identify the degree of technology-discrimination applied by Member States in their notified support schemes. For the second question, we study the actual exemptions invoked to justify deviations from the EEAG's principle of technology-neutrality. First, we count explicit references to one or several of the exemption clauses in point 126 fifth paragraph EEAG. Second, we analyze whether the European Commission invokes additional exemptions not explicitly stated in the non-exhaustive list of point 126 fifth paragraph EEAG. Third, we assess which substantiation beyond the mere assumption that more technologies are better than less technologies - is provided by the European Commission to clarify its understanding of the vague exemption clause Need for diversification (point 126 fifth paragraph (b)).

Our findings are presented in the two sections below. 


\section{EU law vs. reality: EEAG and Member State Practice}

We find a significant discrepancy between the EEAG's technology-neutrality requirement and Member State's inclination to introduce discriminatory RES-E auctions. In 16 out of 18 cases, the European Commission assesses derogations from technology-neutrality, i.e. considers the scheme to be technology-discriminatory. Only two schemes are considered technology-neutral by the European Commission, i.e. Estonia (SA.36023) and Hungary (SA.44076). Applying our own conceptual framework of technology-discrimination, we come to the same conclusion. However, in both cases Member States have only announced that they are planning to introduce technology-neutral auctions in the future without specifying a clear time frame.

Not only are technology-neutral auctions the exception rather than the rule, but we also find the degree to which Member States discriminate between technologies to be high in most cases. According to our classification, seven cases qualify as technology-specific. Another six cases apply multi-technology auctions with additional discriminatory elements, while only one case incorporates multi-technology auctions without such elements. In addition, two cases combine technology-specific and multi-technology auctions with additional discriminatory elements in their schemes, i.e. Germany (SA.45461) and Poland (SA.43697). Table 3 summarizes these findings.

Table 3 Summary of analyzed cases according to the degree of technology-discrimination (N=18)

\begin{tabular}{|c|c|c|c|c|c|}
\hline & $\begin{array}{l}\text { Technology- } \\
\text { neutral }\end{array}$ & $\begin{array}{l}\text { Multi-technol- } \\
\text { ogy without } \\
\text { discriminatory } \\
\text { elements }\end{array}$ & $\begin{array}{l}\text { Multi-technol- } \\
\text { ogy with } \\
\text { discriminatory } \\
\text { elements }\end{array}$ & $\begin{array}{l}\text { Multi-technol- } \\
\text { ogy with } \\
\text { discriminatory } \\
\text { elements \& } \\
\text { technology spe- } \\
\text { cific }\end{array}$ & $\begin{array}{l}\text { Technology } \\
\text { specific }\end{array}$ \\
\hline $\begin{array}{l}\text { Number of } \\
\text { cases }\end{array}$ & 2 & 1 & 6 & 2 & 7 \\
\hline $\begin{array}{l}\text { Case number } \\
\text { (country code) }\end{array}$ & $\begin{array}{l}\text { SA.36023 (EE); } \\
\text { SA.44076 (HU) }\end{array}$ & SA.48238 (FR) & $\begin{array}{l}\text { SA.36196, } \\
\text { SA.47267, } \\
\text { SA.49318 } \\
\text { (UK); } \\
\text { SA.43995 } \\
\text { (MT); } \\
\text { SA.41998 (SI); } \\
\text { SA.40348 (ES) }\end{array}$ & $\begin{array}{l}\text { SA.45461 (DE); } \\
\text { SA.43697 (PL) }\end{array}$ & $\begin{array}{l}\text { SA.39399 (NL); } \\
\text { SA.46259, } \\
\text { SA.46552, } \\
\text { SA.47753, } \\
\text { SA.48066, } \\
\text { SA.49181 (FR); } \\
\text { SA.48143 (GR) }\end{array}$ \\
\hline
\end{tabular}


In this study, we have conducted an analysis based on official state aid decisions released by the European Commission. Previously conducted cross-country and country-specific case studies support our findings. They demonstrate that most EU countries utilize some form of technology-discrimination. ${ }^{29}$ While most Member States have opted for purely technologyspecific auctions (e.g. France, Germany), others rely on heavy discriminatory elements such as technology-specific quotas that increase overall technology-discrimination to a degree similar to technology-specific auctions (e.g. Italy, Spain). Less discriminatory auctions only play a marginal role according to these authors. With respect to the two technology-neutral state aid decisions, we find that Estonia has not yet implemented auctions (as of June 2018). Hungary did change their regulatory framework already in 2017. The new framework features auctions with a high degree of technology differentiation yet it remains unclear if auctions have been conducted since. ${ }^{30}$

\section{The EU Commission's use of Exemptions from Technology-Neutrality}

Against the background of the discrepancy between the EEAG's technology-neutrality requirement and Member State practice, we have studied the application of exemptions: How exactly does the European Commission apply the exemption clauses in its legal assessments of Member States' notified RES-E support schemes? Which and how often exemptions from technology-neutrality are invoked by the Commission? How does the Commission define Need for diversification, given its vagueness and unclear theoretical underpinning relative to the other exemptions in point 126 fifth paragraph EEAG?

Out of the 18 cases, 16 assess exemptions from technology-neutrality. In 14 cases, exemption clauses according to point 126 fifth paragraph EEAG are invoked. Need for diversification is referred to in all 14 cases to justify derogations from technology-neutrality. The second most

\footnotetext{
${ }^{29}$ del Río, supra note 10 at p. 4.; Deutsche Gesellschaft für Internationale Zusammenarbeit (GIZ), Renewable energy auctions. Goal-oriented policy design, 2015, retrieved from https://energypedia.info/images/f/fe/Renewable_Energy_Auctions_(GIZ).pdf.; Wigand et al., supra note 9 at p. 4.

${ }^{30}$ RES Legal, Green Premium II (Tender), 2018, retrieved from http://www.res-legal.eu/search-by-country/hungary/single/s/res-e/t/promotion/aid/green-premium-ii-tender/lastp/143/.
} 
common exemption clause used is Network constraints, which applies to eight cases, followed by System costs and Longer-term potential (used in five cases respectively) (see Figure 2). Two cases make no explicit reference to any of the five exemption clauses. In the case of Spain (SA.40348), the European Commission only states that technology-neutral auctions would lead to a suboptimal result within the meaning of point 126 fifth paragraph EEAG, which is not further specified by invoking one of the five exemption clauses. Moreover, the Malta case (SA.43995) exhibits an additional exemption not explicitly enumerated in point 126 fifth paragraph EEAG (see below).

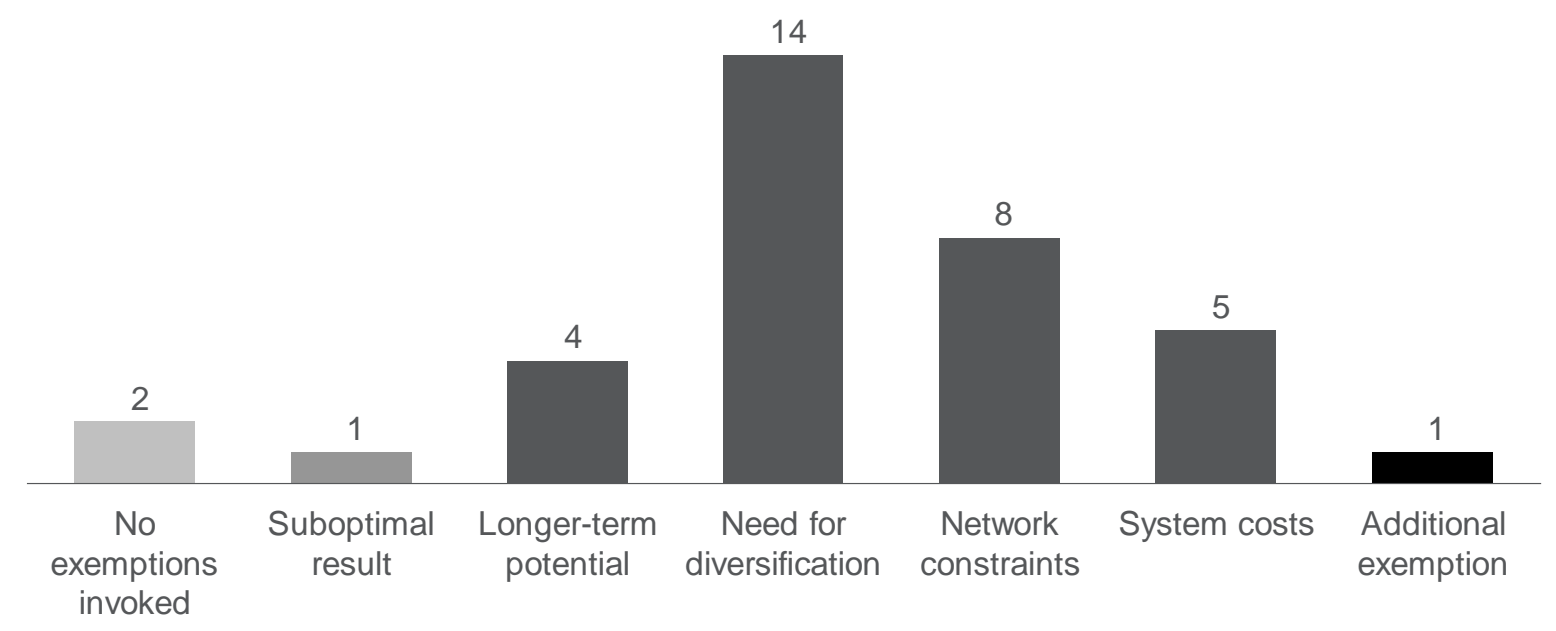

Figure 2: Exemptions invoked by the European Commission to justify derogations from the technologyneutrality requirement (summary). Need for diversification is clearly cited most often, followed by Network constraints. Some of the 18 cases refer to several exemptions, explaining the total number.

Further, we find that the European Commission generally applies between two and four exemption clauses in combination, with only two cases - Slovenia (SA.41998) and France (SA.47753) - featuring the application of Need for diversification as the only exemption clause. In general, various combinations are used. Longer-term potential is only invoked in conjunction with Need for diversification. Network constraints is always applied in combination with Need for diversification, and further supplemented by System costs in four cases. System costs is always used together with Need for diversification and Network constraints. All four exemption clauses according to point 126 fifth paragraph (a) to (d) EEAG are invoked in combination by the European Commission in the case of Germany (SA.45461). The exemption clause of point 126 fifth paragraph (e) EEAG, i.e. Need to avoid distortions on biomass markets, is never invoked by the European Commission. Table 4 summarizes these findings. 


\begin{tabular}{|c|c|c|c|c|c|c|c|c|c|}
\hline & & & $\begin{array}{c}\text { EEAG require- } \\
\text { ment }\end{array}$ & \multicolumn{6}{|c|}{$\begin{array}{c}\text { Exemptions from technology-neutrality } \\
\text { (point } 126 \text { para. } 5 \text { EEAG) }\end{array}$} \\
\hline $\begin{array}{l}\text { Case Num- } \\
\text { ber }\end{array}$ & $\begin{array}{l}\text { Member } \\
\text { State }\end{array}$ & $\begin{array}{l}\text { Decision } \\
\text { date }\end{array}$ & $\begin{array}{l}\text { Technology-neu- } \\
\text { tral }\end{array}$ & $\begin{array}{l}\text { Subop } \\
\text { timal } \\
\text { result }\end{array}$ & $\begin{array}{l}\text { Longer } \\
\text {-term } \\
\text { poten- } \\
\text { tial } \\
\text { (a) }\end{array}$ & $\begin{array}{l}\text { Nee } \\
\text { d } \\
\text { for } \\
\text { di- } \\
\text { vers } \\
\text { ifi- } \\
\text { cati } \\
\text { on } \\
\text { (b) }\end{array}$ & $\begin{array}{l}\text { Net- } \\
\text { work } \\
\text { con- } \\
\text { straint } \\
\text { s (c) }\end{array}$ & $\begin{array}{l}\text { Sys- } \\
\text { tem } \\
\text { cost } \\
\text { s } \\
\text { (d) }\end{array}$ & $\begin{array}{l}\text { Ad- } \\
\text { ditio } \\
\text { nal } \\
\text { ex- } \\
\text { empt } \\
\text { ion }\end{array}$ \\
\hline SA.36196 & $\begin{array}{l}\text { United King- } \\
\text { dom }\end{array}$ & 2014-07-23 & & & $\mathrm{x}$ & $\mathrm{x}$ & & & \\
\hline SA.36023 & Estonia & 2014-10-28 & $\mathrm{x}$ & & & & & & \\
\hline SA.39399 & Netherlands & 2015-04-07 & & & $\mathrm{X}$ & $\mathrm{x}$ & & & \\
\hline SA.43995 & Malta & 2016-08-26 & & & & & & & $\mathrm{x}$ \\
\hline SA.41998 & Slovenia & 2016-10-10 & & & & $\mathrm{x}$ & & & \\
\hline SA.45461 & Germany & 2016-12-20 & & & $\mathrm{x}$ & $\mathrm{x}$ & $\mathrm{x}$ & $\mathrm{x}$ & \\
\hline SA.46259 & France & 2017-02-10 & & & & $\mathrm{x}$ & $\mathrm{x}$ & & \\
\hline SA.47267 & $\begin{array}{l}\text { United King- } \\
\text { dom }\end{array}$ & $2017-02-16$ & & & $\mathrm{x}$ & $\mathrm{x}$ & & & \\
\hline SA.46552 & France & $2017-09-29$ & & & & $\mathrm{x}$ & $\mathrm{x}$ & $\mathrm{x}$ & \\
\hline SA.47753 & France & 2017-09-29 & & & & $\mathrm{x}$ & & & \\
\hline SA.48066 & France & 2017-09-29 & & & & $\mathrm{x}$ & $\mathrm{x}$ & $\mathrm{x}$ & \\
\hline SA.48238 & France & 2017-09-29 & & & & $\mathrm{x}$ & $\mathrm{x}$ & $\mathrm{x}$ & \\
\hline SA.40348 & Spain & 2017-11-10 & & $\mathrm{x}$ & & & & & \\
\hline SA.44076 & Hungary & 2017-11-30 & $\mathrm{x}$ & & & & & & \\
\hline SA.49181 & France & 2017-12-11 & & & & $\mathrm{x}$ & $\mathrm{x}$ & & \\
\hline SA.43697 & Poland & $2017-12-13$ & & & & $\mathrm{x}$ & $\mathrm{x}$ & & \\
\hline SA.48143 & Greece & 2018-01-04 & & & & $\mathrm{x}$ & $\mathrm{x}$ & $\mathrm{x}$ & \\
\hline SA.49318 & $\begin{array}{l}\text { United King- } \\
\text { dom }\end{array}$ & 2018-02-01 & & & $\mathrm{x}$ & $\mathrm{x}$ & & & \\
\hline
\end{tabular}




\begin{tabular}{|l|l|l|l|l|l|l|l|l|l|}
\hline & & Sum & 2 & 1 & 5 & 14 & 8 & 5 & 1 \\
\hline
\end{tabular}

We find that the European Commission hardly makes use of the possibility to invoke exemptions not explicitly listed in point 126 fifth paragraph EEAG. Additional exemptions to justify derogations from technology-neutrality are only used in the case of Malta (SA.43995). Here, the European Commission argues that in light of Geographical and other constraints limiting the potential for the use of RES-E sources, Malta may introduce auctions that restrict participation to onshore wind and solar PV. The exact meaning of this exemption is not further specified, however.

Our analysis provides insights into how the European Commission understands and applies the most frequent exemption clause Need for diversification, which is used in all 14 cases where exemptions from technology-neutrality explicitly stated in point 126 fifth paragraph EEAG are invoked. We find three main argumentative strategies in this respect. First, in ten cases, the European Commission states the Need for diversification without further substantiation, leading to an almost tautological reasoning. Second, in two cases, the Commission interprets this exemption clause in terms of defining elements of Longer-term potential, System costs or Network constraints with no obvious added value. Third, in two cases, the Commission subsumes arguments not accounted for by point 126 fifth paragraph EEAG under the Need for diversification. In the case of Poland (SA.43697), for instance, the exemption is defined in terms of the promotion of technologies with low carbon footprint. Moreover, the contribution of roof-top solar PV to increasing the public acceptability and limiting the environmental impacts of energy transition processes is brought up by the Commission as a rationale for Need for diversification in the case of France (SA.47753). These latter points provide some ideas of how the Need for diversification is conceived of by the European Commission, but a clear-cut definition does not emerge. As a result, the concept remains largely ambiguous even after a comprehensive analysis of recent application practice. This is a major result of our analysis.

Finally, we assess the rigidity of scrutiny of the Commission's assessment of justifications for technology-discrimination and the consistency of its legal assessment across cases. This is of particular importance given the EEAG's overall objective to increase transparency, predictability, and legal certainty for Member States. 
We observe that the rigidity of case scrutiny with regard to applicable exemption clauses differs substantially across cases. On the one extreme, we encounter comprehensive assessments with detailed deduction of conclusions and supplemented by additional empirical evidence provided by Member States. On the other extreme, statements are found to be completely unsubstantiated and lacking basic clarifications on the meaning of and need for certain exemptions. For example, in the case of Malta (SA.43995), the European Commission's assessment of point 126 EEAG covers only three recitals (74-76) and invokes a new exemption referring to Geographical and other constraints, which is not substantiated and thus remains rather vague. By contrast, cases such as Germany (SA.45461) and Slovenia (SA.41998) entail a very high degree of analytical depth. These cases feature comprehensive lines of argumentation leading to the Commission's final application of exemptions and are typically based on substantial empirical evidence and projections provided by Member States. For example, in the case of Slovenia, the European Commission dedicates 20 recitals (113-132) to substantiate its assessment of the scheme's compatibility with point 126 EEAG, elaborating on specific aspects of the scheme design and referring to detailed cost estimates.

Finally, we find inconsistencies in the Commission's legal assessments of RES-E support schemes. First, our analysis reveals that the European Commission applies inconsistent understandings of technology-neutrality. As a case in point, two very similar auction designs - UK (SA. 36196) and Slovenia (SA.41998) - are considered by the European Commission to be technology-neutral in the former case, while the latter is found to be discriminatory. Both schemes feature group-based auctions, in which participation is restricted to a set of technologies. In the UK case, group 1 consists of mature technologies, including onshore wind, solar PV and hydro, which largely overlaps with the group restricted to non-fueled technologies in the Slovenian scheme. This demonstrates that the European Commission applies varying standards with regard to the assessment of technology-neutrality. A second result points to an inconsistency in the actual application of the European Commission's understanding of technology-neutrality. In two very similar auction designs, exemption clauses are assessed in one case - Malta (SA.43995) - but not in the other - Greece (SA.48143) - even though both schemes incorporate pilot joint tenders for solar and wind that are generally found to be discriminatory by the European Commission. However, in the Greek case, exemptions are not explicitly scrutinized, as the European Commission seems to be satisfied by the country's mere commitment to expand the use of technology-neutral auctions in the long-term (recital 60-63). 


\section{Discussion and conclusions}

European Union competition law, intended to thwart subsidies paid out by national governments, plays an important role in shaping European support schemes for renewable energy. In particular, the Environmental and Energy State Aid Guidelines 2014-2020 (EEAG), which formalize the EU Commission's approach to state aid control in the energy sector, prescribe technology-neutral auctions as the standard mechanism to determine support levels for renewable-based electricity generation. As a consequence, Member States need to notify support schemes in advance and get clearance from the Commission.

In this study, we have conducted the first systematic review on the Commission decision practice with respect to technology-neutral auctions by assessing all relevant notifications of RES-E support schemes between 1 July 2014 and 31 May 2018. We were interested in two questions, first to what extent EU Member States implement the EEAG's requirement of technology-neutral auctions and, second, how the Commission justifies derogations from this principle in its state aid decisions. To operationalize the questions, we developed a framework of technology-discrimination, which distinguishes between technology-neutral auctions, multi-technology auctions with and without additional discriminatory elements, and technology-specific auctions.

We find that most notified schemes show a high degree of technology-discrimination. 16 out of 18 schemes are not technology-neutral. Out of the 16, seven are technology-specific, six fall under the category of multi-technology auctions with additional discriminatory elements, and two include technology-specific and multi-technology auctions with additional discriminatory elements simultaneously. Only one scheme belongs to the category of multitechnology auctions without additional discriminatory elements. Moreover, no technologyneutral auction has been conducted under one of the two technology-neutral schemes. It remains to be seen to what degree Hungary and Estonia will introduce discriminatory elements when defining the details of their schemes or when announcing the auction.

To legally reconcile the technology-neutrality requirement on the one hand and Member States' persisting inclination to apply discriminatory RES-E support schemes on the other hand, the Commission invokes exemption clauses. We find that the clause invoked most often is Need for diversification, a poorly defined clause which serves as a de facto residual or catch-all category providing the Commission with enough leeway to justify derogations from the technology-neutrality requirement for diverse reasons. We find three main argumentative 
strategies in this respect. First, the European Commission states the Need for diversification without further substantiation, leading to an almost tautological reasoning. Second, the Commission interprets this exemption clause in terms of defining elements of other exemption clauses. Third, the Commission subsumes arguments not accounted for by the EEAG under the Need for diversification.

We find that the European Commission generally applies between two and four exemption clauses in combination. Need for diversification is, in some cases, invoked together with other exemption clauses, particularly System cost and Network constraints, yet no systematic pattern can be identified. We also find that the level of scrutiny applied varies strongly from case to case and that in many cases the Commission readily accepts Member States' justifications of technology-discrimination without thorough substantiation.

State Aid Guidelines are sectoral protocols published by the European Commission specifying the principles of its application of state aid law. Their purpose is to increase transparency, predictability, and legal certainty for Member States. We find that with respect to technologyneutral auctions for renewable energy, this is not the case: the rule of technology-neutrality in RES-E auctions is almost never followed, and the deviation from the rule is poorly and inconsistently justified. This practice might eventually come at the cost of higher legal uncertainty for Member States.

In our view, it is necessary to establish transparent, predictable criteria and processes to increase rather than decrease legal certainty.

The European Commission could enforce the principle of technology-neutrality more rigorously and try to reduce or even delete the possibility for exemptions during the revision of the EEAG in 2020. The objective of minimizing generation costs would justify such an approach. ${ }^{31}$ However, the Member States' apparent unwillingness to follow this principle as

\footnotetext{
${ }^{31}$ del Río, P. \& Linares, P, Back to the future? Rethinking auctions for renewable electricity support. Renewable and Sustainable Energy Reviews 2014 (35), pp. 42-56.; Iychettira, K. K., Hakvoort, R. A. \& Linares, P., Towards a comprehensive policy for electricity from renewable energy: An approach for policy design. Energy Policy 2017 (106), pp. 169-182.
} 
well as significant scientific arguments against technology-neutral auctions ${ }^{32}$ raise doubts on this approach.

Therefore, the Commission, together with the Parliament and the Council, should define clearer exemptions and establish reliable procedures for their application. The formulation of the RED II would already have been a reasonable place to do so, yet policy makers missed the chance by taking over the wording from the State Aid Guidelines including the imprecise exemption clauses. A thorough investigation and clearer legal definition should be done now as part of the revision of the EEAG.

The new definitions of the principle of technology-neutrality and its exemptions should consider both scientific arguments for and against technology neutrality as mentioned above and the results of this paper. The result of such clarification will also be to the benefit of those Member States whose schemes do not fall under the State Aid Guidelines as the RED II applies to all.

${ }^{32}$ del Río, supra note 10 at p. 4.; Kitzing, L. et al., Recommendations on the role of auctions in a new renewable energy directive. AURES, 2016.; Winkler, Magosch, \& Ragwitz, supra note 10 at p. 4. 